\title{
CEO Exposure, Media Influence, and Stock Returns
}

\author{
Yan Chen, Southwestern University of Finance and Economics, China \\ Changyu $\mathrm{Hu}$, Southwestern University of Finance and Economics, China \\ Wenjie Zhang, Southwestern University of Finance and Economics, China \\ Qing Li, Southwestern University of Finance and Economics, China
}

\begin{abstract}
Media-aware stock movements are well acknowledged by behavioral finance. As the soul of a firm, CEO media behavior is critical to the operation of a firm. CEO exposure could capture the investors' attention and enhance the media effect in the stock market in terms of the "eyeball economics," or CEO overexposure could attract more attention than firm-specific news, which attenuates the media effect in the stock market due to the investors' limited attention. This study systematically explores the role and the moderating effect of CEO media behavior on the relationship between media content and stock markets. Using daily frequency data for a sample of Chinese stocks, this study shows that higher CEO media exposure attenuates the media effect on stock markets, especially consumer-related stocks.
\end{abstract}

\section{KEYWORDS}

CEO Exposure, Industry Classification, Media Effect, News, Stock Market, Text Mining

\section{INTRODUCTION}

In traditional finance, the efficient market hypothesis $(\mathrm{EMH})$ states that a stock price is always driven by "unemotional" investors to equal the firm's rational present value of expected future cash flows (Fama 1965). Specifically, investors are constantly updating their beliefs about the directions of stock markets as they receive new information about relevant firms, although they typically disagree on these directions. This disagreement among competing market participants leads to discrepancies between the actual price and the intrinsic value of a stock, causing the stock price to fluctuate around a stock's intrinsic value. Cutler et al. (1988) found that macroeconomic news could explain approximately one-third of the return variance in the stock market. Mitchell and Mulherin (1994) found that the number of news announcements reported daily by Dow Jones \& Company was directly related to the aggregate measures of stock market activity, including trading volume and market returns.

In addition, recent behavioral finance states that the abnormal fluctuations of stocks are caused by the emotional impulses of irrational investors (De Long et al. 1990; Shleifer and Vishny 1997). In general, investors may be affected by peer opinions from social media or professional attitudes from news articles. Tetlock $(2007,2008)$ analyzed the sentiment polarity of news articles in Wall Street Journal columns and found that stock returns were expected to be low in the presence of negative news 
information. Li et al. (2014a) represented news articles in terms of their nouns and financial sentiment words and found that the sentiment of news articles could be a good indicator of future stock trends.

Although traditional finance and modern behavioral finance have different views on how information shapes stock movements, both believe that the volatility of the stock market comes from the release, dissemination and absorption of information. Today, with the rapid development of information technology, Internet media serve as not only an important channel for investors to access information, but also constitute a key factor affecting investor sentiment and an important "risk source" affecting the stability of the stock market. Some economists have explored the power of news articles on stock market by observing stock movements alongside news feeds, and these studies have shown that in the stock market, with the media serving as the actor and the company serving as the receiver, the fluctuation of stock returns is influenced by media effects and investor cognitive bias and emotional factors (Engelberg, 2008; Kothari et al., 2009; Dougal et al.,2012; Gurun and Butler, 2012; Li et al., 2014; Li et al. 201; Glasserman and Mamaysky, 2019; Jiao et al., 2020). From a management perspective, it is more important that managers play an essential role in market activities, and they may also play a role in the fluctuation of stock prices. As the most critical manager of a firm, the CEO must realize the indispensable effect of the media on firm operations. The media portray CEO performance, which could shape the public's perceptions of a CEO's abilities and company performance (Liu, McConnell and $\mathrm{Xu}, 2017$ ).

CEOs can maintain the company's favorable image in the public's mind through engaging with the media, including clarifying rumors in time, disclosing information accurately and strengthening communication with the media (Bednar, 2012; Elliott et al., 2018). Meanwhile, the exposure of negative news on a CEO could be damaging to stocks. For example, on September 24, 2018, Jingdong's (JD's) stock price fell by $7.47 \%$ with the biggest intraday drop of $8.14 \%$, leading to a sharp decline in its market value, when a sexual abuse scandal concerning its CEO Qiangdong Liu was exposed. In addition, some CEOs maintain their companies' image by increasing their personal exposure, including being exclusively interviewed on television, holding their own press conferences and endorsing the company's new products.

On the one hand, the CEO's media exposure can capture the public's attention and enhance the popularity of the firm to a certain extent, which may bring about "eyeball economics" benefits, similar to the star effect. In particular, when the CEO's exposure attracts public attention to the firm, the news articles related to the firm will also be immediately captured and absorbed by the public, which can be reflected in the stock market. For example, Aouadi (2013) suggested that investor attention is a determinant of French stock market activity and volatility. Fang et al. (2014) provided evidence that an increase in individual investors' attention to stock and the market return provide joint effects on the daily stock return. Zhang and Wang (2015) utilized the Baidu index as a proxy for individual investors' attention and found that high investor attention induces upward pressure on the market within the week and that this pressure will reverse in a short time.

On the other hand, cognitive psychology states that people's attention is a type of limited cognitive resource. That is, the public's attention to something must come at the expense of attention to something else (Kahneman, 1973). Therefore, when overloaded by massive amounts of CEO information, the public's capacity and efficiency of processing other information will be greatly reduced (Posner and Boies,1971). For instance, Hamilton and Zeckhauser (2004) found that CEO news attracts more attention than valuable firm news because the public prefers personal stories on the CEO, especially negative news. It is of great interest to determine whether the high media exposure of the CEO enhances media-aware stock movements by attracting the eyeballs of investors as a star or reducing the media effect on stock returns by causing visual fatigue among investors.

As a common role in news, CEOs' media exposure plays an indispensable role in many aspects of a firms' performance, and it has been frequently recognized by researchers that CEO characteristics (e.g., age, gender, and experience) are significantly correlated with firm performance (Cianci and Kaplan, 2010; Francis, Huang, Rajgopal, and Zang, 2008; Jian and Lee, 2011, Oesterle et al., 2016; 
Fralicha and Bitektineb, 2020). Moreover, in recent years, some studies have indicated that a CEO's personality traits can affect stock prices, suggesting that a CEO's exposure in the media may raise the company's profile and have a positive impact on stock returns (Malmendier and Tate 2009; Tetlock 2011). Previous studies have focused on the impact of company news and CEO media exposure on company stock returns, though to the best of our knowledge, prior research has rarely examined the role of CEO media exposure in the relationship between the media and stock market performance. Based on the theory of limited attention, does the strong propaganda created through CEOs' media exposure capture investors' attention and increase their sensitivity to firm-specific news, enhancing the media effect on stock markets, or does CEO overexposure produce noise information and interfere with investors' information processing, attenuating the impact of firm-specific news on relevant stock performance? To address these issues, this study quantifies the media's influence on stock markets to investigate the role of CEOs, as recommended by Tetlock $(2007,2008)$. Such quantification is achieved by analyzing the sentiment of each news article. Then, we estimate the relationship between news article sentiment and stock performance by extending Fama and French's three-factor model and the capital asset pricing model (CAPM). In addition, this study examines the role of CEO exposure in the relationship between stock returns and news articles in different industry sectors. The study attempts to reveal the effect of CEO media exposure on news article sentiment and stock performance and put forward new findings on the media effects of the Chinese stock market and of other emerging stock markets.

\section{Literature Review and Hypotheses Development}

\section{Media Effect On Stock Markets}

The influence of the media on stock markets has been frequently recognized by researchers, including economists, computer scientists, and managerialists (Li et al. 2018; Glasserman and Mamaysky, 2019; Jiao et al., 2020). They have explored the power of the media's effect on stock markets by observing abnormal fluctuations of stock markets. In early stages of this research, due to the limitations of text mining techniques, traditional finance studies used the number of news articles as an indicator of the influence of news articles. For instance, Mitchell and Mulherin (1994) found a direct, robust relation between the number of news articles reported daily by Dow Jones and stock market activity, including trading volume, market returns, and firm-specific returns. Chan (2003) found that stocks with news exhibit multimonth momentum, while stocks without news tend to reverse in the subsequent month.

In fact, modern behavioral finance has discovered that abnormal fluctuations of stocks are caused by the emotional impulses of irrational investors (Shleifer and Vishny 1997). Emotional fluctuations and investment decisions of investors may be affected by professional or peer opinions from news articles (Carretta et al. 2011). Fundamental information from firm-specific news articles can enrich the knowledge of investors and affect their trading activities (Li et al., 2014). Quantifying the influence of news articles using news counts is too simple; thus, researchers have adopted natural language-processing techniques, especially sentiment analysis, to extract valuable information from news articles. For example, Tetlock (2007) measured the negative (positive) sentiment polarity of articles in terms of the proportion of negative (positive) emotional words in the document and found that stock returns were expected to be low in the presence of negative news information. Both Bollen et al. (2011) and Schumaker (2012) utilized OpinionFinder, a document-level sentiment analyzer, to calculate the sentiment index of each news article and found that this index obviously improved predictive precision.

In general, news articles with positive (negative) sentiment tend to have a positive (negative) impact on stock returns. Researchers believe that the media coverage of positive news convinces investors that a company has better future prospects and that the stock price will increase. For instance, Solomon (2012) found that positive news stories raise investor expectations of a firm's future profitability, leading to stock price increases in the short term. Meanwhile, negative sentiment tends to generate downward stock price pressure. For instance, Tetlock et al. (2008) measured the 
contents of news articles by standardizing the fraction of negative words and found that high media pessimism robustly predicts downward pressure on market prices. Heston and Sinha (2017) measured sentiment with a proprietary Thomson Reuters neural network and found that positive news increases stock returns quickly, while negative stories spurs a long-delayed reaction. Li et al. (2020) used economic indicators and news sentiment to predict stock price and found both factors can achieve better prediction effect.

However, the above in-depth research on media-aware stock movements is based on the developed stock market. The mechanisms of media percolation and its impact on stock markets are diverse among different countries (Calomiris and Mamaysky 2019). As suggested by Griffin, Hirschey, and Kelly (2011), in most developed markets, a firm's stock is more volatile on days on which there is public news about the firm. In emerging markets, however, volatility does not occur on either news or no-news days. It is of significance to determine whether we can obtain the same conclusion in the Chinese stock market as in the US stock market; that is, the sentiment of news articles has an impact on stock movements, as Tetlock (2008) suggested. Hence, the first hypothesis of this study is as follows:

Hypothesis One (H1): In Chinese stock markets, the sentiment of news articles has an impact on stock movements.

\section{Investors' Limited Attention and CEO Media Exposure}

An assumption often made in the financial literature is that investors have infinite cognitive resources. However, cognitive psychology states that people's attention is a type of limited cognitive resource. That is, the public's attention to something must come at the expense of attention to something else (Kahneman, 1973). The allocation of individual investors' attention directly affects their decisions in the financial market, and the function and nature of investors' attention have important effects on financial markets, especially the stock market. Their limited attention restricts the public's ability to process information. Previous studies have provided evidence that investors tend to focus on familiar or attention-grabbing stocks and that information may not be incorporated into prices until it attracts the attention of investors (DellaVigna and Pollet, 2009; Feng and Hu, 2014; Zhang and Wang, 2015). Choi and Choi (2019) found that the effect of attention on stock returns is short-lived and disappears within two days, which means that the rise in stock prices is related to behavioral bias rather than fundamental information.

The CEO is generally regarded as the soul of a firm. Upper echelons theory states that organizational outcomes are partially affected by the top management team, especially the CEO, the core member of the top management team (Hambrick and Mason, 1984). Previous studies have examined various aspects of the CEO and the resultant impact on firms' strategic decision making (Carmeli et al., 2012; Oesterle et al., 2016; Fralicha and Bitektineb, 2020), firm performance (Nguyen and Leblanc, 2001; Barker and Mueller, 2002;Peni, 2014), and relevant stock performance (Kim et al., 2016; Andreou et al., 2017; Al Mamun et al.,2020; Chen et al., 2021). Moreover, in recent years, some studies have indicated that a CEO's personality traits can affect stock prices. Jeong-Bon Kim et al. (2016) found that firms with an overconfident CEO are more likely to show high risks of stock price collapse. Ya You (2020) proposed how CEO characteristics can influence innovation and stock returns.

More importantly, as the most important member of the key decision-making groups in a firm, the CEO has the power of direct control over firms' strategic alternatives. The CEO can realize the important effect of the media on firm operations and maintain the company's favorable image in the public's mind through engaging with media, including clarifying rumors in time, disclosing information accurately and strengthening communication with the media. In addition, some CEOs maintain the corporate image by increasing their personal exposure, including being exclusively interviewed on television, holding their own press conferences and endorsing the company's new 
products. It is of great interest to determine whether the high media exposure of the CEO enhances media-aware stock movements by attracting the eyeballs of investors as a star or reducing the media effect on stock returns by causing visual fatigue among investors.

Obviously, unlike company news, CEO news includes considerably more personal information than information on company operations. Whether it involves image building or sharing information on personal details, we cannot ignore the subtle influence of this kind of exposure on a company's media effects. Previous studies have focused on the impact of CEO media exposure on a company's stock price, though to the best of our knowledge, prior research has rarely examined the role of CEO media exposure in the relationship between the media and stock market performance. In general, the high exposure of CEOs may capture the public's attention and enhance the popularity of the firms and their relevant stocks to a certain extent, which could enhance the media effect on stock returns. In particular, when the CEO's exposure attracts public attention for the firm, the news articles related to the firm will also be immediately captured and absorbed by the public, which can be reflected in the stock market. For example, Bednar (2012) argued that CEOs' high media exposure will have a good impact on the firm because media coverage plays the role of a watchdog to reduce information asymmetry between management and external constituents. Qiao, Fung and Wang (2018) showed that CEO media coverage has a wide dispersion and mitigates firms' crash risk. Nguyen (2015) found that firms with the highest level of CEO media coverage outperform those with the lowest levels by $8 \%$ in abnormal stock returns.

Indeed, according to the limited attention hypothesis, the public's attention to something must come at the expense of attention to something else (Kahneman, 1973); that is, investors may pay too much attention to the high exposure of CEOs and thus underreact to other valuable media reports, reducing the media effect on stock returns. When overloaded by massive amounts of CEO information, the public's capacity and efficiency of processing other information will be greatly reduced (Posner and Boies,1971). For instance, Hamilton and Zeckhauser (2004) found that CEO's news attracts more attention than valuable firm news because the public prefers personal stories on the CEO, especially negative news. Hirshleifer, Lim and Teoh (2011) found that the neglect of earnings components by investors with limited attention causes accrual and cash flow anomalies.

Therefore, we believe that the high media exposure of CEOs weakens the media effect on stock returns by occupying the limited attention of the public. Hence, the second formal hypothesis to address in this study is as follows:

Hypothesis Two (H2): In Chinese stock markets, the high media exposure of CEOs weakens the relationship between the media and stock market performance.

Figure 1 places CEO exposure within a conceptual framework illustrating its moderating role in the relationship between the media and stock returns.

\section{Media Exposure Effects In Different Industries}

From the perspective of industry attributes, previous studies have found that the performance of listed firms in the stock market depends to some extent on the characteristics of their industries. King et al. (1966) proposed that compared with noncyclical industries, cyclical industries face greater industry risks due to their high correlation with the external macroeconomic environment, and therefore, their stock volatility is more intense. Moskowitz and Grinblatt (1999) argued that the momentum effect is more obvious in industries with good development momentum. Ronald and Tjeert (2004) used a multivariate regression method and found that the differences between the effects of equity allocation are still substantial in both the long term and the short term.

In fact, investors' attention varies in different industries. For example, the financial industry, as a barometer of the national economy, the wholesale and retail industry, which is closely related to people's daily life, and the real estate industry, which is related to people's livelihood, are subjects of 


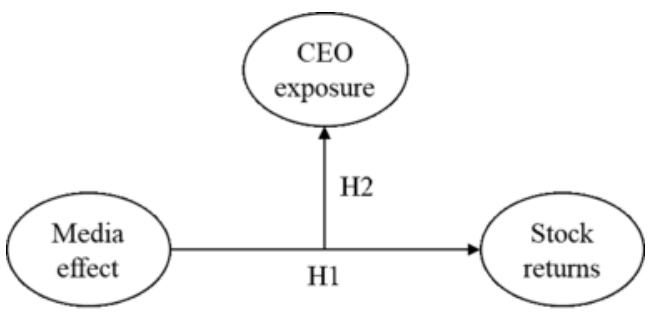

high public concern and attract a high degree of investor attention. In addition, the media behavior of company managers varies by industry. Some firms are good at using the media to create the corporate image, while others may choose to keep a low profile and develop steadily. For example, CEOs who act as corporate decision makers and image spokesmen, such as Ma Huateng of Tencent and Elon Musk of Tesla in the information technology industry and Wang Shi of Vanke and Wang Jianlin of Wanda in the real estate industry, are inclined to increase their media exposure to improve the company's image in the media. Therefore, the influence of CEOs' media behavior may vary by industry, and the same media behavior by different CEOs has varying degrees of influence on stock returns due to the disparity among industries.

Currently, only a few studies have explored the differences in stock market performance in an industry from the perspective of investors. Huang (2014) constructed the investor sentiment index by using fundamental and trading information for the stock market and found that the index has the strongest correlation with stock market volatility in the information industry and the weakest correlation with that in the transportation industry. Rehman (2016) followed Huang's index construction method to explore the time-frequency relationship between investor sentiment and specific returns for nine industries. Consequently, we believe that the impact of investor sentiment based on news articles on the stock market is different in various industries. Meanwhile, considering investor attention and CEO media behavior among industries, we will further explore the difference in the influence of CEO media behavior in different industries on the media effect on stock returns. It is believed that due to the different industries of listed firms, CEO exposure has different moderating effects on the media effect on stock returns. Hence, the third hypothesis of this study is as follows:

Hypothesis Three (H3): In Chinese stock markets, the media exposure of CEOs in different industries has different moderating effects between the media effect and stock market performance.

\section{EXPERIMENT DATA}

\section{Sample and Data}

To examine whether the media and CEO exposure have different effects on different stocks, we partition the listed firms into 5 industrial sectors, i.e., information technology, finance, wholesale and retail trade, culture, sports and entertainment and real estate, and the testing period ranges from January 2015 to December 2017. The analysis in this paper combines two types of data (i.e., market and news), both of which are aggregated into a single dataset at the day-firm level. The market data, i.e., stock record transaction data, include the market value, turnover, current ratio, stock price, market return, and stock return, which are obtained from the China Securities Market Research Database (www. gtarsc.com), the largest and most accurate financial and economic database in China. In selecting the sample, firms with (1) special treatment by stock exchanges ${ }^{\mathrm{i}}$ or (2) more than one-quarter of the data 
missing due to stock suspension are excluded. The final sample covers 595 listed firms in Chinese stock markets in total.

In addition, a firm-specific news article conveys information on the fundamentals and management of a certain firm. To obtain such news, we gather all the news articles on 32 mainstream financial websites in China, including eastmoney.com and hexun.com, for the period between 2015 and 2017. Specifically, we first apply our focused Web crawler to download relevant news web pages from these websites. Second, titles, publishers, release time, and the body of news articles are extracted from the acquired web page. Third, we adopt bloom filters to detect and remove duplicate news articles and keep only the news articles with company names in the content. Finally, after the removal of the HTML tags of each news article, the news content, relevant listed firm name and publication date are stored in the database. In total, the database contains 272,124 news articles related to 595 listed firms. An overview of the news articles can be found in Table 1.

\section{Measure of News Articles}

Tetlock (2007) presented an effective approach to quantify news articles for the study of media-aware stock movements. This approach measures the content of news articles by standardizing the fraction of emotional words in each news article. In unreported tests, the study finds very similar results using combined measures of positive $(P)$ and negative $(N)$ words, such as $(P-N) /(P+N)$ and $\log ((1+P) /(1+N))$. However, using negative words in isolation produces much weaker results, especially after controlling for positive words. These results are consistent with Solomon (2012) and Shiller (2015), who argued that positive information has a stronger impact than negative information and is more likely to be generated by firms when the news is good, thus increasing the amount of investors' attention given to positive stories.

We first require that each news article contains at least 30 words in the news body and at least 5 words that are either "positive" or "negative", where at least 3 of the 5 must be unique. We then combine all qualifying news articles for each firm on a given trading day into a single composite article. We standardize the fraction of positive words in each composite news article by subtracting the prior year's mean and dividing by the prior year's standard deviation of the fraction of positive words. Formally, following Tetlock (2007), we define the measure of positive words as

$$
p o s=\frac{\text { Pos }-\mu P o s}{\sigma P o s}
$$

where Pos is the ratio of positive words to the total number of words in an in the daily composite news article. $\mu$ Pos and $\sigma$ Pos are the means and the standard deviations of Pos over the prior calendar year, respectively. In addition, the variable pos is set to zero if no news articles are released on a day. The variable pos is the stationary measure of news content that we employ in our regression analyses.

Note that Tetlock (2007) analyzed the content of news articles using a general-domain emotional word dictionary (Harvard-IV-4). As per Loughran and McDonald (2012), general sentiment words may not be emotional in the realm of finance. Therefore, to improve the precision of sentiment analysis, we determine the sentiment of news articles in terms of the finance-specific sentiment word list of Li et al. (2014b) rather than general sentiment words.

\section{Measure of CEO Media Exposure}

The measure of CEO media exposure is based on Milbourn (2003) and is equal to the number of news articles citing the CEO. CEO media exposure is defined as the amount of media coverage on 
Table 1. Summary statistics for the news articles dataset

\begin{tabular}{|c|c|c|c|c|c|c|}
\hline Firm category & IT & FINANCE & WRT & C\&S\&E & RE & $\begin{array}{c}\text { Full } \\
\text { Sample }\end{array}$ \\
\hline No. of firms & 208 & 68 & 154 & 46 & 119 & 595 \\
\hline No. of news articles & 81,918 & 48,460 & 55,752 & 27,960 & 58,034 & 272,124 \\
\hline $\begin{array}{l}\text { No. of news articles per } \\
\text { firm }\end{array}$ & 394 & 713 & 362 & 608 & 488 & 457 \\
\hline $\begin{array}{l}\text { No. of news articles per } \\
\text { day }\end{array}$ & 75 & 44 & 51 & 26 & 53 & 249 \\
\hline $\begin{array}{l}\text { No. of news articles per } \\
\text { firm per day }\end{array}$ & 0.36 & 0.65 & 0.33 & 0.56 & 0.45 & 0.42 \\
\hline No. of news of CEOs & 7,648 & 4,861 & 5,541 & 3,485 & 6,386 & 27,921 \\
\hline $\begin{array}{l}\text { The fraction of CEO news } \\
\text { in total news }\end{array}$ & 0.09 & 0.10 & 0.10 & 0.12 & 0.11 & 0.10 \\
\hline $\begin{array}{c}\text { Max No. of news articles } \\
\text { of a firm }\end{array}$ & 1,746 & 2,020 & 1,246 & 1,545 & 1,503 & 2,020 \\
\hline $\begin{array}{c}\text { Min No. of news articles } \\
\text { of a firm }\end{array}$ & 67 & 181 & 79 & 75 & 43 & 43 \\
\hline $\begin{array}{l}\text { No. of total words per } \\
\text { news article }\end{array}$ & 324 & 364 & 351 & 375 & 353 & 348 \\
\hline $\begin{array}{l}\text { No. of positive words per } \\
\text { news article }\end{array}$ & 36 & 41 & 34 & 38 & 35 & 36 \\
\hline $\begin{array}{c}\text { No. of negative words per } \\
\text { news article }\end{array}$ & 10 & 14 & 11 & 10 & 11 & 11 \\
\hline
\end{tabular}

Notes: This table presents the descriptions of the news article dataset for the 2015-2017 sample period in terms of 5 industry sectors. Industry classification is performed using Classification of National Economic Industries (GB/T4754) codes to identify 5 different industries: information technology (IT); finance; wholesale and retail trade (WRT); culture, sports and entertainment (C\&S\&E); and real estat (RE).

the CEO in a quarter divided by the total number of news articles at the firm level. Specifically, we first select the news about CEOs by retrieving the name of the CEO of each firm from our news article database and then calculate the proportion of CEO news in the total news in a quarter. Finally, we define an indicator variable to represent higher and lower CEO media exposure ${ }^{2}$. CEO Media Exposure takes a value of 1 when the CEO media exposure for a firm is in the top half of those for all firms and 0 otherwise.

\section{Empirical Analysis and Results}

We study the impact of the media on stock returns by standardizing the fraction of positive words in each news story. Baker and Jeffrey (2006) forecast the returns of various high-minus-low portfolios (in terms of sensitivity to sentiment) by adding sentiment indexes into the Fama-French three-factor model. They found that a wave of investor sentiment has larger effects on stocks than low levels of investor sentiment. Therefore, we evaluate the effect of firm-specific news content on stock returns by adding news indicators to the Fama-French three-factor model. However, to make the results more robust, we also use Sharpe and William's (1964) capital asset pricing model (CAPM) and compare both models. In addition, based on the aforementioned principle, we further examine the role of CEO exposure in the relationship between the media and stock returns in 5 industry sectors. 


\section{Media Effect On Stock Returns}

To test our first hypothesis, we propose that news articles with high media optimism predict upward pressure on market prices. We test the following regression model based on the Fama-French (1993) three-factor model (FF3) between stock returns and the news article emotion factor $\left(\right.$ pos $\left._{i, t}\right)$ :

$$
r_{i, t}-r_{f, t}=\alpha_{i}+\beta_{i}\left(r_{M, t}-r_{f, t}\right)+s_{i} S M B_{t}+h_{i} H M L_{t}+\lambda_{i} \operatorname{pos}_{i, t}+\varepsilon_{i, t}
$$

where $r_{i, t}$ is the rate of return of stock $i$ on day $t, r_{f, t}$ is the daily market risk-free rate of return on day $t^{t h}, r_{M, t}$ is the rate of return of the market on day $t$, and $r_{M, t}-r_{f, t}$ denotes the excess return on the market portfolio on day $t . S M B_{t}$ is the size risk factor, that is, the "small market capitalization minus the large market capitalization" on day $t . H M L_{t}$ is the value risk factor, that is, the "high book-to-market ratio minus the low book-to-market ratio" on day $t . S M B_{t}$ and $H M L_{t}$ are used to measure the historic excess returns of small capital over large capital and of value stocks over growth stocks, respectively. $\operatorname{pos}_{i, t}$ denotes the news article emotion factor of stock $i$ on day $t . \alpha, \beta$, $s_{i}, h_{i}$ and $\lambda$ are the parameters to be estimated. $\varepsilon$ is the idiosyncratic error term.

Following Fama and French (1993), we first split stocks in each industry in half based on the market capitalization of stocks. We further split each group into three subgroups in terms of the book-to-market ratios. Finally, we calculate the SMB (small minus large) factor and HML (high minus low) factor based on the average return on the six portfolios. The risk-free rate $r_{f, t}$ is measured by the bank's three-month time deposit rate in the same period divided by 90 . We use the rate of return of the sector index in each industry as a proxy for the rate of return of the market $r_{M, t}$. Table 2 presents the definitions of the variables used in this study.

In addition, to make the results more robust, we extend the CAPM by adopting the news article emotion factor $\left(\right.$ pos $\left._{i, t}\right)$ to capture the media effect on stock returns as follows:

$$
r_{i, t}-r_{f, t}=\alpha_{i}+\beta_{i}\left(r_{M, t}-r_{f, t}\right)+\lambda_{i} \operatorname{pos}_{i, t}+\varepsilon_{i, t}
$$

where $r_{i, t}$ is the rate of return of stock $i$ on day $t, r_{f, t}$ is the daily market risk-free rate of return on day $t, r_{M, t}$ is the rate of return of the market on day $t$, and $r_{M, t}-r_{f, t}$ denotes the excess return on the market portfolio on day $t \cdot$ pos $_{i, t}$ denotes the news article emotion factor of stock $i$ on day t. $\alpha, \beta$ and $\lambda$ are the parameters to be estimated. $\mu$ is the idiosyncratic error term. The OLS estimates of the coefficients $\lambda$ in equations (2) and (3) are the primary focus of this study.

Table 3 tests our first hypothesis concerning the effect of news articles with positive sentiment on stock returns in Chinese stock markets and shows the results for 57,893 news articles based on 595 stocks in 5 industry sectors. The results of the news factors obtained from the Fama-French three-factor model are consistent with those from the CAPM model. This consistency illustrates the robustness of the results.

To simplify our explanation, we explain only the experimental results based on the Fama-French three-factor model in the following sections.

The estimated coefficients of news factors in the IT, FINANCE, WRT, C\&S\&E, and RE industry sectors are $0.0027,0.0011,0.0017,0.0011$, and 0.0010 , respectively, and are statistically significant at the $1 \%$ level. According to the standard deviation of each industry sector (i.e., IT $=0.480$, FINANCE 
Table 2. Definitions of the variables

\begin{tabular}{|c|c|}
\hline Variables & Description and measure \\
\hline $\boldsymbol{r}_{i}$ & The daily rate of return of the stock. \\
\hline$r_{M}$ & $\begin{array}{l}\text { The rate of return of the relevant sector index (real estate, finance, wholesale and retail } \\
\text { trade, information technology and culture, sports and entertainment). }\end{array}$ \\
\hline $\boldsymbol{r}_{f}$ & $\begin{array}{l}\text { The risk-free rate measured by the bank's three-month time deposit rate in the same } \\
\text { period divided by } 90 \text {. }\end{array}$ \\
\hline$S M B$ & $\begin{array}{l}\text { The average return on the three small portfolios (that is, with small market } \\
\text { capitalization) minus the average return on the three big portfolios (large market } \\
\text { capitalization). }\end{array}$ \\
\hline$H M L$ & $\begin{array}{l}\text { The average return on the two value portfolios (that is, with high BE/ME ratios) minus } \\
\text { the average return on the two growth portfolios (low BE/ME ratios). }\end{array}$ \\
\hline pos & Measure of news articles through positive emotion words. \\
\hline CEOEXPOSURE & $\begin{array}{l}\text { A dummy variable that equals one if the CEO media exposure for a firm is in the top } \\
\text { half of those of all firms, and zero otherwise. }\end{array}$ \\
\hline
\end{tabular}

Notes: This table presents the definitions of the variables used in thisstudy.

$=1.158, \mathrm{WRT}=0.872, \mathrm{C} \& \mathrm{~S} \& \mathrm{E}=1.072$ and $\mathrm{RE}=0.531)$, we find that a one-standard-deviation increase in pos leads to $0.130 \%\left(0.0027^{*} 0.48\right), 0.127 \%\left(0.0011^{*} 1.158\right), 0.148 \%(0.0017 * 0.872)$, $0.118 \%(0.0011 * 1.072)$ and $0.0531 \%(0.0010 * 0.531)$ increases in the stock returns to the yields of IT, FINANCE, WRT, C\&S\&E, and RE industry sectors, respectively. Therefore, stocks in WRT are more sensitive to news articles because consumer-related industry news articles are of strong interest to the public or related to daily life and more rigorously considered, which is consistent with $\mathrm{Li}$ et al. (2014a). Consistent with our prediction, the result indicates that news articles with higher positive sentiment have a positive effect on stock returns, which is in line with prior literature. Das and Chen (2007) and Schumaker et al. (2012) found that optimistic news tends to have a positive impact on stock returns. This result corroborates the basic assertion in behavioral finance that investors are sentimental (De Long et al. 1990). Turning to our other variables, we find that the signs of the coefficients have important economic significance. First, the coefficient of market factors $\left(r_{M, t}-r_{f, t}\right)$ is close to 1 ; that is, the market factor is positively related to stock returns. The volatility of industry sectors follows the direction of market fluctuations. Second, the size risk factor (SMB) is positively associated with stock returns; that is, the stock returns of small-market-capitalization firms exceeded those of large-market-capitalization firms. Third, the value risk factor (HML) is negatively related to stock returns, which states that the stock returns of firms with low book-to-market ratios exceeded those of firms with high book-to-market ratios.

\section{Does CEO Media Exposure Weaken The Media Effect on Stock Returns?}

To test our second hypothesis that CEO media exposure has a negative moderating effect on the relationship between the media and stock returns in Chinese stock markets, we include CEO media exposure ( $C E O E X P O S U R E$ ) and additional interaction term ( $C E O E X P O S U R E^{*}$ pos ) in our main regression:

$$
r_{i, t}-r_{f, t}=\alpha_{i}+\lambda_{i} \operatorname{pos}_{i, t}+c_{i} \text { CEOEXPOSURE }{ }_{i, t}+\gamma_{i} \operatorname{pos}_{i, t}{ }^{*} \text { CEOEXPOSURE }
$$


Table 3. The impact of news articles ( $p o s$ ) on stock returns $(r)$

\begin{tabular}{|c|c|c|c|c|c|c|c|c|c|c|}
\hline \multirow{2}{*}{ Variables } & \multicolumn{2}{|c|}{ IT } & \multicolumn{2}{|c|}{ FINANCE } & \multicolumn{2}{|l|}{ WRT } & \multicolumn{2}{|l|}{ C\&S\&E } & \multicolumn{2}{|c|}{$\mathbf{R E}$} \\
\hline & FF3 & CAPM & FF3 & CAPM & FF3 & CAPM & FF3 & CAPM & FF3 & CAPM \\
\hline pos & $\begin{array}{l}0.0027 * * * \\
(5.322)\end{array}$ & $\begin{array}{l}0.0029 * * * \\
(5.499)\end{array}$ & $\begin{array}{l}0.0011 * * * \\
(9.047)\end{array}$ & $\begin{array}{l}0.0011^{* * * *} \\
(8.622)\end{array}$ & $\begin{array}{c}0.0017^{* * * *} \\
(14.896)\end{array}$ & $\begin{array}{c}0.0018 * * * \\
(14.594)\end{array}$ & $\begin{array}{l}0.0011 \text { *** } \\
(4.937)\end{array}$ & $\begin{array}{l}0.0010^{* * * *} \\
(4.491)\end{array}$ & $\begin{array}{l}0.0010^{* * * *} \\
(5.114)\end{array}$ & $\begin{array}{l}0.0010^{* * * *} \\
(4.924)\end{array}$ \\
\hline$r_{M}-r_{f}$ & $\begin{array}{l}0.990^{* * *} \\
(62.217)\end{array}$ & $\begin{array}{l}1.3111 * * * * \\
(85.464)\end{array}$ & $\begin{array}{l}1.132^{* * * *} \\
(124.689)\end{array}$ & $\begin{array}{l}1.078^{* * * *} \\
(124.589)\end{array}$ & $\begin{array}{l}1.035^{* * *} \\
(167.117)\end{array}$ & $\begin{array}{l}1.255^{* * *} \\
(201.142)\end{array}$ & $\begin{array}{l}0.972^{* * * *} \\
(66.832)\end{array}$ & $\begin{array}{l}1.218^{* * * *} \\
(83.810)\end{array}$ & $\begin{array}{l}1.081^{* * * *} \\
(183.194)\end{array}$ & $\begin{array}{l}1.250^{* * *} \\
(213.026)\end{array}$ \\
\hline$S M B$ & $\begin{array}{l}0.593^{* * *} \\
(15.432)\end{array}$ & & $\begin{array}{l}-0.387 * * * * \\
(-17.487)\end{array}$ & & $\begin{array}{l}0.727^{* * * *} \\
(47.606)\end{array}$ & & $\begin{array}{l}0.512^{2 * * *} \\
(14.385)\end{array}$ & & $\begin{array}{l}0.715^{* * * *} \\
(47.408)\end{array}$ & \\
\hline$H M L$ & $\begin{array}{l}-1.285 * * * \\
(-23.370)\end{array}$ & & $\begin{array}{l}-0.184 * * * \\
(-5.779)\end{array}$ & & $\begin{array}{l}-0.443 * * * \\
(-20.244)\end{array}$ & & $\begin{array}{r}-0.919 * * * * \\
(-18.081)\end{array}$ & & $\begin{array}{l}-0.075 \text { **** } \\
(-3.389)\end{array}$ & \\
\hline Year FE & Yes & Yes & Yes & Yes & Yes & Yes & Yes & Yes & Yes & Yes \\
\hline Adjust $\mathbf{R}^{2}$ & $8.89 \%$ & $5.80 \%$ & $27.8 \%$ & $26.90 \%$ & $37.14 \%$ & $28.92 \%$ & $28.72 \%$ & $20.97 \%$ & $46.03 \%$ & $39.73 \%$ \\
\hline Observations & 119,084 & 119,084 & 42,374 & 42,374 & 99,968 & 99,968 & 26,534 & 26,534 & 68,894 & 68,894 \\
\hline
\end{tabular}

Notes: This table shows the effect of news articles (pos) on firms' returns in terms of 5 industry sectors. Industry classification is performed using Classification of National Economic Industries (GB/T4754) codes to identify 5 different industries: information technology (IT); finance; wholesale and retail trade (WRT); culture, sports and entertainment (C\&S\&E); and real estate (RE). CAPM is used to examine the robustness of our main inference. The estimation models are year fixed effects OLS regressions. The figures in parentheses are t-statistics. Superscripts ${ }^{\star \star *}$, ${ }^{* \star}$, and ${ }^{*}$ indicate significance at the $1 \%, 5 \%$, and $10 \%$ levels, respectively.

$$
+\beta_{i}\left(r_{M, t}-r_{f, t}\right)+s_{i} S M B_{t}+h_{i} H M L_{t}+\varepsilon_{i, t}
$$

where CEOEXPOSURE $E_{i, t}$ is the CEO media exposure for the firm of stock $i$ on day $t$. $C E O E X P O S U R E$ is set to one if the CEO media exposure for a firm is in the top half of the distribution; otherwise, it is set to zero.

To make the results more robust, we further extend the CAPM by adopting the news article emotion factor, CEO media exposure and an additional interaction term to test whether CEO media exposure negatively moderates the relationship between the media and stock market performance as follows:

$$
\begin{aligned}
& \quad r_{i, t}-r_{f, t}=\alpha_{i}+\lambda_{i} \operatorname{pos}_{i, t}+c_{i} \text { CEOEXPOSURE } E_{i, t}+\gamma_{i} \operatorname{pos}_{i, t}{ }^{*} \operatorname{CEOEXPOSURE}_{i, t} \\
& +\beta_{i}\left(r_{M, t}-r_{f, t}\right)+\varepsilon_{i, t}
\end{aligned}
$$

To test our third hypothesis, we examine the above 2 regression models' interaction term ( pos* CEOEXPOSURE) in 5 industry sectors.

Table 4 shows the test results for the role of CEO media exposure in the relationship between the media and stock returns in 5 industry sectors. To test the moderation and industry hypotheses, the key variable of interest here is interaction term ( $p o s^{*} C E O E X P O S U R E$ ). The interaction term captures the difference in the effects of the media on stock market performance between firms with high and low CEO media exposure. Equally important, the coefficient on pos captures the effects of news articles for firms with lower CEO media exposure. The results of the news factors and interaction term obtained from the Fama-French three-factor model are consistent with those 
from the CAPM model. Such consistency shows the robustness of our results. To simplify our explanation, we explain only the experimental results based on the Fama-French three-factor model in the following. To more clearly express the results, Table 5 presents the details for the moderating effect of CEO media exposure on this relationship.

The coefficient estimates of the interaction term, pos* CEOEXPOSURE, are negative and statistically significant in the FINANCE, WRT, C\&S\&E and RE industry sectors. Specifically, according to the standard deviation of each industry sector (i.e., IT $=0.480$, FINANCE $=1.158$, $\mathrm{WRT}=0.872, \mathrm{C} \& \mathrm{~S} \& \mathrm{E}=1.072$ and $\mathrm{RE}=0.531$ ), we find that the estimation result for the FINANCE industry sector shows that a one-standard-deviation increase in pos leads to a $0.290 \%$ (i.e., $0.0025^{*} 1.158$ ) increase in stock returns for firms with less CEO media exposure, and a one-standarddeviation increase in pos leads to a $0.116 \%$ (i.e., $0.0025 * 1.158+(-0.0018) * 1.158$ ) increase in stock returns for firms with more CEO media exposure. Similarly, in terms of WRT, C\&S\&E and RE industry sectors, for firms with low CEO media exposure, a one-standard-deviation increase in pos is associated with an increase of $0.262 \%, 0.214 \%$ and $0.112 \%$ (i.e., $0.0030 * 0.872,0.0020 * 1.072$ and $0.0021 * 0.531)$ in stock returns, respectively, while for firms with high CEO media exposure, such an increase is associated with an increase of $0.096 \%, 0.064 \%$ and $0.021 \%$ (i.e., $0.0030 * 0.872+(-$ $0.0019) * 0.872,0.0020 * 1.072+(-0.0014) * 1.072$ and $0.0021 * 0.531+(-0.0017) * 0.531)$ in stock returns, respectively. Therefore, the second hypothesis is partially supported, and in general, the presence of a CEO with more media exposure negatively moderates the association between the media effect and stock returns, suggesting that the positive relationship between news positive sentiment and stock returns is more pronounced for firms with less CEO exposure. This may be the case because the public's capacity to efficiently process other valuable media reports will be greatly reduced when overloaded with massive amounts of CEO information (Posner and Boies,1971). Soft or negative news on CEOs attracts more attention than valuable firm news reported by online media, which seems to weaken the relation between the media and stock returns.

Furthermore, the coefficient estimates of pos $^{*} C E O E X P O S U R E$ for the IT industry sector are positive and significant at the $1 \%$ level. The coefficient estimates of CEOEXPOSURE are not significant. These results show that greater CEO media exposure is positively moderated. As is shown, the estimation result for the IT industry sector shows that a one-standard-deviation increase in pos leads to a $0.181 \%$ (i.e., $-0.00012 * 0.48+0.0039 * 0.48$ ) increase in stock returns for firms with more CEO media exposure, while there is no significant relationship between news articles and stock returns with less CEO media exposure. In addition, the association between news articles and stock returns is less pronounced when CEO exposure is higher in the other four industry sectors. Specifically, among the four industries, the greater CEO exposure of the FINANCE industry sector has the strongest moderating effect $\left(0.0018^{*} 1.158=-0.208 \%\right)$, while the RE industry sector shows the weakest effect $(-0.0017 * 0.531=-0.09 \%)$. Accordingly, supporting our third hypothesis, different industries show moderating effects of CEO exposure to varying degrees. This may be because investor attention varies across different industries, and CEO exposure has different moderating effects on the media effect on stock returns.

In summary, the above analysis indicates that (1) news articles with high levels of media optimism induce upward pressure on stock market activity; (2) this relationship is weaker in the presence of greater CEO media exposure; and (3) the role of CEO media exposure in different industries shows different moderating effects between media effects and stock market performance.

\section{DISCUSSION}

This study systematically explores the relationship between media content and stock returns and the moderating effect of CEO media exposure on that relationship by using information on a large 
Table 4. The moderating effect of CEO media exposure on the relationship between the media and stock returns

\begin{tabular}{|c|c|c|c|c|c|c|c|c|c|c|}
\hline \multirow[b]{2}{*}{ Variables } & \multicolumn{2}{|l|}{ IT } & \multicolumn{2}{|c|}{ FINANCE } & \multicolumn{2}{|l|}{ WRT } & \multicolumn{2}{|c|}{ C\&S\&E } & \multicolumn{2}{|l|}{ RE } \\
\hline & FF3 & CAPM & FF3 & CAPM & FF3 & CAPM & FF3 & CAPM & FF3 & CAPM \\
\hline pos & $\begin{array}{l}-0.00012 \\
(-0.121)\end{array}$ & $\begin{array}{l}0.000033 \\
(0.033)\end{array}$ & $\begin{array}{l}0.0025^{\text {**** }} \\
(10.249)\end{array}$ & $\begin{array}{l}0.0026^{* * * *} \\
(10.425)\end{array}$ & $\begin{array}{l}0.0030^{* * * * *} \\
(15.508)\end{array}$ & $\begin{array}{l}0.0030^{* * * *} \\
(14.886)\end{array}$ & $\begin{array}{l}0.0020^{* * * *} \\
(5.454)\end{array}$ & $\begin{array}{l}0.0019^{* * * *} \\
(4.830)\end{array}$ & $\begin{array}{l}0.0021^{\text {**** }} \\
(6.463)\end{array}$ & $\begin{array}{l}0.0017^{* * * *} \\
(4.367)\end{array}$ \\
\hline CEOEXPOSURA & $\begin{array}{l}0.001 * * \\
(2.108)\end{array}$ & $\begin{array}{l}0.001 * * * \\
(2.734)\end{array}$ & $\begin{array}{l}-0.0002 \\
(-0.434)\end{array}$ & $\begin{array}{l}0.0001 \\
(0.381)\end{array}$ & $\begin{array}{c}-0.0001 \\
(-0.615)\end{array}$ & $\begin{array}{l}0.00005 \\
(0.204)\end{array}$ & $\begin{array}{l}0.0001 \\
(0.071)\end{array}$ & $\begin{array}{l}0.0003 \\
(0.594)\end{array}$ & $\begin{array}{l}0.0001 \\
(0.667)\end{array}$ & $\begin{array}{l}-0.0003 \\
(-1.201)\end{array}$ \\
\hline pos * CEO EXPOSURE & $\begin{array}{l}0.0039^{* * * * *} \\
(3.326)\end{array}$ & $\begin{array}{l}0.0039^{* * * *} \\
(3.248)\end{array}$ & $\begin{array}{l}-0.0018^{* * * *} \\
(-6.296)\end{array}$ & $\begin{array}{c}-0.0020^{* * * *} * \\
(-6.798)\end{array}$ & $\begin{array}{l}-0.0019^{* * * *} \\
(-7.640)\end{array}$ & $\begin{array}{l}-0.0019 * * * \\
(-7.26)\end{array}$ & $\begin{array}{l}-0.0014^{* * * *} \\
(-2.934)\end{array}$ & $\begin{array}{l}-0.0013 * * * * \\
(-2.628)\end{array}$ & $\begin{array}{l}-0.0017^{* * *} * \\
(-4.120)\end{array}$ & $\begin{array}{l}-0.0010^{* *} \\
(-2.068)\end{array}$ \\
\hline$r_{M}-r_{f}$ & $\begin{array}{l}0.991^{* * * *} \\
(62.239)\end{array}$ & $\begin{array}{l}1.312 * * * \\
(85.488)\end{array}$ & $\begin{array}{l}1.131^{* * * *} \\
(124.706)\end{array}$ & $\begin{array}{l}1.078^{* * * *} \\
(124.628)\end{array}$ & $\begin{array}{c}1.034 * * * \\
(167.211)\end{array}$ & $\begin{array}{l}1.256^{* * * *} \\
(201.243)\end{array}$ & $\begin{array}{l}0.972 * * * \\
(66.857)\end{array}$ & $\begin{array}{l}1.218^{* * * *} \\
(83.836)\end{array}$ & $\begin{array}{l}1.079 * * * \\
(180.166)\end{array}$ & $\begin{array}{l}1.250^{* * * *} \\
(212.99)\end{array}$ \\
\hline$S M B$ & $\begin{array}{l}0.593 * * * \\
(15.434)\end{array}$ & & $\begin{array}{l}-0.388^{* * *} * \\
(-17.494)\end{array}$ & & $\begin{array}{l}0.727 * * * \\
(47.604)\end{array}$ & & $\begin{array}{l}0.512^{* * * *} \\
(14.396)\end{array}$ & & $\begin{array}{l}0.709^{* * * *} \\
(45.395)\end{array}$ & \\
\hline$H M L$ & $\begin{array}{l}-1.284 * * * \\
(-23.357)\end{array}$ & & $\begin{array}{l}-0.185^{* * * *} \\
(-5.826)\end{array}$ & & $\begin{array}{l}-0.444^{* * * *} \\
(-20.286)\end{array}$ & & $\begin{array}{l}-0.920^{* * * *} \\
(-18.093)\end{array}$ & & $\begin{array}{l}-0.071^{* * * *} \\
(-3.153)\end{array}$ & \\
\hline Year FE & Yes & Yes & Yes & Yes & Yes & Yes & Yes & Yes & Yes & Yes \\
\hline Adjust $\mathrm{R}^{2}$ & $8.90 \%$ & $5.81 \%$ & $27.9 \%$ & $27.0 \%$ & $37.18 \%$ & $28.96 \%$ & $28.74 \%$ & & $45.90 \%$ & $39.74 \%$ \\
\hline Observations & 119,084 & 119,084 & 42,374 & 42,374 & 99,968 & 99,968 & 26,534 & 26,534 & 68,894 & 68,894 \\
\hline
\end{tabular}

Notes: This table provides the results of a test of the moderating effect of CEO media exposure on the relationship between the media and stock returns for 5 industry sectors. Industry classification is performed using Classification of National Economic Industries (GB/T4754) codes to identify 5 different industries: information technology (IT); finance; wholesale and retail trade (WRT); culture, sports and entertainment (C\&S\&E); and real estate (RE). CAPM is used to examine the robustness of our main inference. The estimation models are year fixed effects OLS regressions. The figures in parentheses are t-statistics. Superscripts ${ }^{* * *}$, ${ }^{* *}$, and ${ }^{*}$ indicate significance at the $1 \%, 5 \%$, and $10 \%$ levels, respectively.

sample of Chinese listed firms in 5 industry sectors obtained from the CSMAR database and online media data for the period 2015-2017.

The straightforward and effective quantitative measure of news article emotion can be used to study media-aware stock movements in Chinese stock markets that appear to correspond to either positive investor sentiment or positive sentiment conveyed by the media. We document that positive

Table 5. The effect of the media on the stock returns of firms with low/high CEO media exposure

\begin{tabular}{|c|l|l|l|l|l|}
\hline $\begin{array}{c}\text { Industry } \\
\text { sector }\end{array}$ & \multicolumn{1}{|c|}{$\begin{array}{c}(\mathbf{1}) \\
\text { Std.dev. }\end{array}$} & \multicolumn{1}{|c|}{$\begin{array}{c}(\mathbf{2}) \\
\mathbf{p o s}\end{array}$} & $p o s^{*}$ CEOEXPOSURE & $\begin{array}{c}\text { (4) } \\
\text { Low } \\
\text { exposure }\end{array}$ & $\begin{array}{c}\mathbf{( 5 )} \\
\text { High } \\
\text { exposure }\end{array}$ \\
\hline IT & 0.480 & -0.00012 & $0.0039 * * *$ & -0.00576 & 0.18144 \\
\hline FINANCE & 1.158 & $0.0025 * * *$ & $-0.0018 * * *$ & 0.2895 & 0.08106 \\
\hline WRT & 0.872 & $0.0030^{* * *}$ & $-0.0019 * * *$ & 0.2616 & 0.09592 \\
\hline C\&S\&E & 1.072 & $0.0020^{* * *}$ & $-0.0014 * * *$ & 0.2144 & 0.06432 \\
\hline RE & 0.531 & $0.0021^{* * *}$ & $-0.0017 * * *$ & 0.11151 & 0.02124 \\
\hline
\end{tabular}

Notes: The first column reports the standard deviation of the variable pOS for 5 industry sectors. Columns (2) and (3) report the estimation results of Eq. (4). Column (4) (column (5)) shows the effect of the media on the stock market performance of firms with low (high) CEO media exposure, which is calculated by column (1) $\times$ column (2) (column (1) $\times$ column (2) + column (1) $\times$ column (3)). One basis point in the last two columns equals a daily return of $1 \%$. Superscripts ${ }^{* * *},{ }^{* *}$, and ${ }^{*}$ indicate significance at the $1 \%, 5 \%$, and $10 \%$ levels, respectively. 
sentiment in news articles positively affects stock returns and find that, generally, the interaction between more CEO media exposure and news articles negatively affects stock returns. This evidence is strong and consistent for five different industry sectors, i.e., information technology, finance, wholesale and retail trade, culture, sports and entertainment, and real estate. As predicted, different industries show moderating effects of CEO exposure to varying degrees. Our results hold when we use two different models, i.e., the Fama-French three-factor model and the capital asset pricing model.

First, we draw the same conclusion for the Chinese stock market as we do for the US stock market in that the media seem to be able to enhance stock value by improving the fraction of positive words within news articles and improving investor sentiment. According to the empirical study of five industry sectors of Chinese stock markets, we came to the same conclusion that news articles with more positive sentiment have a more positive effect on stock returns, which is in line with prior literature. Das and Chen (2007) and Schumaker et al. (2012) found that optimistic news tends to have a positive impact on stock returns. This is consistent with sentiment theory under the assumption that media content is linked to the behavior of individual investors. Moreover, we find that stocks in the wholesale and retail trade industry sector are more sensitive to news articles because consumer news articles are more rigorously considered by the public than news on other firms, which is consistent with Li et al. (2014a).

Second, the findings of this study imply that the association between news articles and stock returns is less pronounced when CEO media exposure is higher, indicating that the public is highly interested in CEO-related news and that the public usually ignores firm-related coverage on online media, which is consistent with Posner and Boies (1971). Specifically, cognitive psychology states that people's attention is a type of limited cognitive resource; when overloaded by massive amounts of CEO information, the public's capacity and efficiency of processing other information will be greatly reduced. This may be the case because soft and negative news on CEOs attracts more attention than valuable firm news reported by online media (Gamache and McNamar, 2019), which tends to weaken the relationship between the media and stock returns.

Third, our findings suggest that CEO exposure has different moderating effects on the media effect on stock returns in different industry sectors. Specifically, frequent media coverage of an CEO enhances media-aware stock movements in the IT industry, while it weakens the relation between news articles and stock returns in the other four industry sectors studied, especially in the financial industry sector. This may be the case because, first, the IT industry has rapidly developed in recent years, especially in the realm of AI technology, and fourth- and fifth-generation communication technologies and chips have always been hot topics of discussion. Therefore, as a sunrise industry, the IT industry has been the focus of considerable investor attention, and CEO's media exposure can attract the public's interest and enhance the popularity of the firm to a certain extent. Second, new product launches in most IT firms are usually hosted by CEOs themselves, and the popularity of new product promotion is often accompanied by the exposure of CEOs. CEOs' performance may even grab more public attention than the products, and information overload will reduce investors' capacity to deal with the valuable news on the companies themselves. Moreover, comparatively speaking, in the financial industry, due to its particularities (that is, in serving both the real economy and other industries), CEOs are more cautious about exposure in the public and at work, which may also lead to their news information attracting more investor attention.

\section{Conclusion}

This study investigates how news article content affects stock returns and the moderating effect of CEO media exposure on this relationship using a large sample of Chinese listed firms for the period of 2005-2017. We find that positive sentiment in news articles is positively associated with stock returns and that the interaction between higher CEO exposure and news articles is negatively related to stock value. Meanwhile, different industries show moderating effects of $\mathrm{CEO}$ exposure of varying degrees. Based on a quantitative analysis of mass news media information, this study presents new 
results on the three areas of media effects, CEO exposure and industry effects to further explore the influential mechanisms of Chinese stock markets. In addition, through an analysis of the moderating effects of different industries, our research provides new perspectives for use in corporate governance, supervision, risk prevention and control.

While the results show that positive sentiment of news articles may enhance the value of relevant stocks and that CEO media exposure negatively moderates the relationship between the media and stock returns, we emphasize that our study is not free from limitations. First, although we identify CEO media exposure as a negative moderator of the relationship under study, we believe that other moderators not considered in this study may affect this relationship, such as ownership structures, executive incentives, and product market competition. It would be interesting to explore them in future work. Second, our sample consists only of Chinese listed firms and thus can reflect only the situation in emerging markets. Future research could include emerging markets and developed markets, which may have different mechanisms of online media percolation and the extent of its impact on stock returns.

\section{ACKNOWLEDGMENT}

This work was supported by the National Natural Science Foundation of China (NSFC) [71671141, 71873108, and 62072379]; the Department of Science and Technology of Sichuan Province [2019YJ0250 and 2020ZYD018]; and the Key Laboratory of Financial Intelligence and Financial Engineering of Sichuan Province. 


\section{REFERENCES}

Al Mamun, M., Balachandran, B., \& Duong, H. N. (2020). Powerful CEOs and stock price crash risk. Journal of Corporate Finance, 62, 101582. doi:10.1016/j.jcorpfin.2020.101582

Andreou, P. C., Louca, C., \& Petrou, A. P. (2017). CEO age and stock price crash risk. Review of Finance, 21(3), 1287-1325. doi:10.1093/rof/rfw056

Aouadi, A., Arouri, M., \& Teulon, F. (2013). Investor attention and stock market activity: Evidence from France. Economic Modelling, 35, 674-681. doi:10.1016/j.econmod.2013.08.034

Baker, M., \& Wurgler, J. (2006). Investor sentiment and the cross-section of stock returns. The Journal of Finance, 61(4), 1645-1680. doi:10.1111/j.1540-6261.2006.00885.x

Barker, V. L. III, \& Mueller, G. C. (2002). CEO characteristics and firm R\&D spending. Management Science, 48(6), 782-801. doi:10.1287/mnsc.48.6.782.187

Bednar, M. K. (2012). Watchdog or lapdog? A behavioral view of the media as a corporate governance mechanism. Academy of Management Journal, 55(1), 131-150. doi:10.5465/amj.2009.0862

Bollen, J., Mao, H., \& Zeng, X. (2011). Twitter mood predicts the stock market. Journal of Computational Science, 2(1), 1-8. doi:10.1016/j.jocs.2010.12.007

Calomiris, C. W., \& Mamaysky, H. (2019). How news and its context drive risk and returns around the world. Journal of Financial Economics, 133(2), 299-336. doi:10.1016/j.jfineco.2018.11.009

Carmeli, A., Tishler, A., \& Edmondson, A. C. (2012). CEO relational leadership and strategic decision quality in top management teams: The role of team trust and learning from failure. Strategic Organization, 10(1), 31-54. doi: $10.1177 / 1476127011434797$

Carretta, A., Farina, V., Martelli, D., Fiordelisi, F., \& Schwizer, P. (2011). The impact of corporate governance press news on stock market returns. European Financial Management, 17(1), 100-119. doi:10.1111/j.1468036X.2010.00548.x

Chan, W. S. (2003). Stock price reaction to news and no-news: Drift and reversal after headlines. Journal of Financial Economics, 70(2), 223-260. doi:10.1016/S0304-405X(03)00146-6

Chen, Y., Fan, Q., Yang, X., Yanan, W., \& Zolotoyt, L. (2021). CEO early-life disaster experience and stock price crash risk. Journal of Corporate Finance, 101928. doi:10.1016/j.jcorpfin.2021.101928

Choi, S., \& Choi, W. Y. (2019). Effects of limited attention on investors' trading behavior: Evidence from online ranking data. Pacific-Basin Finance Journal, 56, 273-289. doi:10.1016/j.pacfin.2019.06.007

Cianci, A. M., \& Kaplan, S. E. (2010). The effect of CEO reputation and explanations for poor performance on investors' judgments about the company's future performance and management. Accounting, Organizations and Society, 35(4), 478-495. doi:10.1016/j.aos.2009.12.002

Cutler, D. M., Poterba, J. M., \& Summers, L. H. (1988). What moves stock prices? (No. w2538). National Bureau of Economic Research. doi:10.3386/w2538

Das, S. R., \& Chen, M. Y. (2007). Yahoo! for Amazon: Sentiment extraction from small talk on the web. Management Science, 53(9), 1375-1388. doi:10.1287/mnsc.1070.0704

De Long, J. B., Shleifer, A., Summers, L. H., \& Waldmann, R. J. (1990). Noise trader risk in financial markets. Journal of Political Economy, 98(4), 703-738. doi:10.1086/261703

DellaVigna, S., \& Pollet, J. M. (2009). Investor inattention and Friday earnings announcements. The Journal of Finance, 64(2), 709-749. doi:10.1111/j.1540-6261.2009.01447.x

Dougal, C., Engelberg, J., Garcia, D., \& Parsons, C. A. (2012). Journalists and the stock market. Review of Financial Studies, 25(3), 639-679. doi:10.1093/rfs/hhr133

Elliott, W. B., Grant, S. M., \& Hodge, F. D. (2018). Negative news and investor trust: The role of Firm and CEO Twitter use. Journal of Accounting Research, 56(5), 1483-1519. doi:10.1111/1475-679X.12217 
Engelberg, J. (2008). Costly information processing: Evidence from earnings announcements. In AFA 2009 San Francisco meetings paper.

Fama, E. F. (1965). The behavior of stock-market prices. The Journal of Business, 38(1), 34-105. doi:10.1086/294743

Fama, E. F., \& French, K. R. (1993). Common risk factors in the returns on stocks and bonds. Journal of Financial Economics, 1993(33), 3-56. doi:10.1016/0304-405X(93)90023-5

Fang, X., Jiang, Y., \& Qian, Z. (2014). The effects of individual investors' attention on stock returns: Evidence from the ChiNext market. Emerging Markets Finance and Trade, 50(sup3), 158-168.

Feng, X., \& Hu, N. (2014). Are individual investors affected by attention? China Finance Review International. doi:10.1108/CFRI-09-2013-0114

Fralich, R., \& Bitektine, A. (2020). "Invincibles" and "invisibles": CEO status and the 'Matthew effect' in strategic decision-making. Long Range Planning, 53(3), 101887. doi:10.1016/j.lrp.2019.05.007

Francis, J., Huang, A. H., Rajgopal, S., \& Zang, A. Y. (2008). CEO reputation and earnings quality. Contemporary Accounting Research, 25(1), 109-147. doi:10.1506/car.25.1.4

Gamache, D. L., \& McNamara, G. (2019). Responding to bad press: How CEO temporal focus influences the sensitivity to negative media coverage of acquisitions. Academy of Management Journal, 62(3), 918-943. doi:10.5465/amj.2017.0526

Glasserman, P., \& Mamaysky, H. (2019). Does unusual news forecast market stress? Journal of Financial and Quantitative Analysis, 54(5), 1937-1974. doi:10.1017/S0022109019000127

Griffin, J. M., Hirschey, N. H., \& Kelly, P. J. (2011). How important is the financial media in global markets? Review of Financial Studies, 24(12), 3941-3992. doi:10.1093/rfs/hhr099

Gurun, U. G., \& Butler, A. W. (2012). Don't believe the hype: Local media slant, local advertising, and firm value. The Journal of Finance, 67(2), 561-598. doi:10.1111/j.1540-6261.2012.01725.x

Hambrick, D. C., \& Mason, P. A. (1984). Upper echelons: The organization as a reflection of its top managers. Academy of Management Review, 9(2), 193-206. doi:10.5465/amr.1984.4277628

Hamilton, J. T., \& Zeckhauser, R. (2004). Media coverage of CEOs: who? what? where? when? why? Unpublished working paper, Stanford Institute of International Studies.

Heston, S. L., \& Sinha, N. R. (2017). News vs. sentiment: Predicting stock returns from news stories. Financial Analysts Journal, 73(3), 67-83. doi:10.2469/faj.v73.n3.3

Hirshleifer, D., Lim, S. S., \& Teoh, S. H. (2011). Limited investor attention and stock market misreactions to accounting information. Review of Asset Pricing Studies, 1(1), 35-73. doi:10.1093/rapstu/rar002

Huang, C., Yang, X., Yang, X., \& Sheng, H. (2014). An empirical study of the effect of investor sentiment on returns of different industries. Mathematical Problems in Engineering, 2014, 2014. doi:10.1155/2014/545723

Jian, M., \& Lee, K. W. (2011). Does CEO reputation matter for capital investments? Journal of Corporate Finance, 17(4), 929-946. doi:10.1016/j.jcorpfin.2011.04.004

Jiao, P., Veiga, A., \& Walther, A. (2020). Social media, news media and the stock market. Journal of Economic Behavior \& Organization, 176, 63-90. doi:10.1016/j.jebo.2020.03.002

Kahneman, D. (1973). Attention and effort (Vol. 1063). Prentice-Hall.

Kim, J. B., Wang, Z., \& Zhang, L. (2016). CEO overconfidence and stock price crash risk. Contemporary Accounting Research, 33(4), 1720-1749. doi:10.1111/1911-3846.12217

King, B. F. (1966). Market and industry factors in stock price behavior. The Journal of Business, 39(1), 139-190. doi: $10.1086 / 294847$

Kothari, S. P., Li, X., \& Short, J. E. (2009). The effect of disclosures by management, analysts, and business press on cost of capital, return volatility, and analyst forecasts: A study using content analysis. The Accounting Review, 84(5), 1639-1670. doi:10.2308/accr.2009.84.5.1639 
Li, Q., Chen, Y., Wang, J., Chen, Y., \& Chen, H. (2017). Web media and stock markets: A survey and future directions from a big data perspective. IEEE Transactions on Knowledge and Data Engineering, 30(2), 381-399. doi:10.1109/TKDE.2017.2763144

Li, Q., Wang, T., Gong, Q., Chen, Y., Lin, Z., \& Song, S. K. (2014). Media-aware quantitative trading based on public Web information. Decision Support Systems, 61, 93-105. doi:10.1016/j.dss.2014.01.013

Li, Q., Wang, T., Li, P., Liu, L., Gong, Q., \& Chen, Y. (2014). The effect of news and public mood on stock movements. Information Sciences, 278, 826-840. doi:10.1016/j.ins.2014.03.096

Li, X., Wu, P., \& Wang, W. (2020). Incorporating stock prices and news sentiments for stock market prediction: A case of Hong Kong. Information Processing \& Management, 57(5), 102212. doi:10.1016/j.ipm.2020.102212

Liu, B., McConnell, J. J., \& Xu, W. (2017). The power of the pen reconsidered: The media, CEO human capital, and corporate governance. Journal of Banking \& Finance, 76, 175-188. doi:10.1016/j.jbankfin.2016.12.004

Loughran, T., \& McDonald, B. (2011). When is a liability not a liability? Textual analysis, dictionaries, and 10-Ks. The Journal of Finance, 66(1), 35-65. doi:10.1111/j.1540-6261.2010.01625.x

Malmendier, U., \& Tate, G. (2009). Superstar ceos. The Quarterly Journal of Economics, 124(4), 1593-1638. doi:10.1162/qjec.2009.124.4.1593

Milbourn, T. T. (2003). CEO reputation and stock-based compensation. Journal of Financial Economics, 68(2), 233-262. doi:10.1016/S0304-405X(03)00066-7

Mitchell, M. L., \& Mulherin, J. H. (1994). The impact of public information on the stock market. The Journal of Finance, 49(3), 923-950. doi:10.1111/j.1540-6261.1994.tb00083.x

Moskowitz, T. J., \& Grinblatt, M. (1999). Do industries explain momentum? The Journal of Finance, 54(4), 1249-1290. doi:10.1111/0022-1082.00146

Nguyen, B. D. (2015). Is more news good news? Media coverage of CEOs, firm value, and rent extraction. The Quarterly Journal of Finance, 5(04), 1550020. doi:10.1142/S2010139215500202

Nguyen, N., \& Leblanc, G. (2001). Corporate image and corporate reputation in customers' retention decisions in services. Journal of Retailing and Consumer Services, 8(4), 227-236. doi:10.1016/S0969-6989(00)00029-1

Oesterle, M. J., Elosge, C., \& Elosge, L. (2016). Me, myself and I: The role of CEO narcissism in internationalization decisions. International Business Review, 25(5), 1114-1123. doi:10.1016/j.ibusrev.2016.02.001

Peni, E. (2014). CEO and chairperson characteristics and firm performance. The Journal of Management and Governance, 18(1), 185-205. doi:10.1007/s10997-012-9224-7

Posner, M. I., \& Boies, S. J. (1971). Components of attention. Psychological Review, 78(5), 391-408. doi:10.1037/ h0031333

Qiao, P. H., Fung, H. G., \& Wang, W. (2018). Chinese firms' crash risk and CEO media exposure. Applied Economics Letters, 25(14), 1034-1037. doi:10.1080/13504851.2017.1420871

Rehman, M. U., \& Shahzad, S. J. H. (2016). Investors' sentiments and industry returns: Wavelet analysis through Squared Coherency Approach. ACRN Oxford Journal of Finance and Risk Perspectives, 5, 151-162.

Schumaker, R. P., Zhang, Y., Huang, C. N., \& Chen, H. (2012). Evaluating sentiment in financial news articles. Decision Support Systems, 53(3), 458-464. doi:10.1016/j.dss.2012.03.001

Sharpe, W. F. (1964). Capital asset prices: A theory of market equilibrium under conditions of risk. The Journal of Finance, 19(3), 425-442.

Shiller, R. J. (2015). Irrational exuberance: Revised and expanded (3rd ed.). Princeton University Press. doi: $10.2307 /$ j.ctt1287kz5

Shleifer, A., \& Vishny, R. W. (1997). The limits of arbitrage. The Journal of Finance, 52(1), 35-55. doi:10.1111/j.1540-6261.1997.tb03807.x

Solomon, D. H. (2012). Selective publicity and stock prices. The Journal of Finance, 67(2), 599-638. doi:10.1111/j.1540-6261.2012.01726.x 
Tetlock, P. C. (2007). Giving content to investor sentiment: The role of media in the stock market. The Journal of Finance, 62(3), 1139-1168. doi:10.1111/j.1540-6261.2007.01232.x

Tetlock, P. C. (2011). All the news that's fit to reprint: Do investors react to stale information? Review of Financial Studies, 24(5), 1481-1512. doi:10.1093/rfs/hhq141

Tetlock, P. C., Saar-Tsechansky, M., \& Macskassy, S. (2008). More than words: Quantifying language to measure firms' fundamentals. The Journal of Finance, 63(3), 1437-1467. doi:10.1111/j.1540-6261.2008.01362.x

Van Dijk, R., \& Keijzer, T. (2003). Region, sector and style selection in global equity markets. Journal of Asset Management, 4(5), 293-307. doi:10.1057/palgrave.jam.2240110

You, Y., Srinivasan, S., Pauwels, K., \& Joshi, A. (2020). How CEO/CMO characteristics affect innovation and stock returns: Findings and future directions. Journal of the Academy of Marketing Science, 1-25.

Zhang, B., \& Wang, Y. (2015). Limited attention of individual investors and stock performance: Evidence from the ChiNext market. Economic Modelling, 50, 94-104. doi:10.1016/j.econmod.2015.06.009

\section{ENDNOTES}

1 When the situation, especially the financial situation, of a listed firm worsens, the Shenzhen and Shanghai stock exchanges will give special treatment to the firm. The volatility of the relevant stocks is limited within a small range.

2 The authors also apply CEO media exposure measures as a continuous variable to conduct all the related tests and find that the results are also strong and consistent with the findings presented here.

Yan Chen is an Assistant Professor at Southwestern University of Finance and Economics, China. His research interests lie primarily in data mining and financial intelligence. He has published his paper in IEEE Transactions on Knowledge and Data Engineering and Emerging Market Finance and Trade.

Changyu Hu received the bachelor's degree from Hefei University, in 2019. She is working toward the PhD degree at Southwestern University of Finance and Economics, China. Her research interests lie primarily in financial intelligence and Management Information System. Wenjie Zhang is an Assistant Professor at Southwestern University of Finance and Economics, China. Her research interests lie primarily in internet finance, finance technology and business intelligence. She has published her paper in Online Information Review.

Qing Li is a professor at Southwestern University of Finance and Economics, China. Prior to taking that post, he was a postdoctoral researcher at Arizona State University and at the Information \& Communications University of Korea. Li's research interests lie primarily in intelligent information processing and business intelligence. He has served on the editorial boards of Electronic Commerce Research and Applications, the Journal of Database Management, and the Journal of Global Information Management as well as the program committees of various international conferences, including PACIS, SIGIR, and CIKM. He received his Ph.D. from Kumoh National Institute of Technology in February of 2005 and his M.S. and B.S. degrees from Harbin Engineering University, China. 